\title{
Spatial variation in the intertidal bivalve Macoma balthica: biotic variables in relation to density and abiotic factors
}

\author{
Lamia Azouzi ${ }^{1}$, Edwin Bourget ${ }^{2, *}$, Daniel Borcard ${ }^{3}$ \\ ${ }^{1}$ ISMER, 310 allée des Ursulines, Rimouski, Québec G5L 3A1, Canada \\ ${ }^{2}$ GIROQ, Département de Biologie, Université Laval, Québec, Québec G1K 7P4, Canada \\ ${ }^{3}$ Département de Sciences Biologiques, Université de Montréal, CP 6128, Succursale Centre-ville, Montréal, \\ Québec H3C 3J7, Canada
}

\begin{abstract}
We studied the spatial variation in biotic variables of a Macoma balthica population. Systematic sampling was carried out over an environmentally heterogeneous intertidal bay of the St. Lawrence Estuary. Several biotic (density, body tissue and shell mass, reproductive effort, shell length and growth) and abiotic (intertidal level, sediment characteristics) variables were concurrently analysed to quantify the part of the variance accounted for by the abiotic factors and the part accounted for by density (density was also studied as an explanatory variable). Redundancy analysis and multiple regression were used. The variables examined were mapped to show the trends in their spatial variation. Density was highly variable, from 0 to 2700 ind. $\mathrm{m}^{-2}$, and was mainly positively related to the percentage of sand in the sediment. Most biotic variables were spatially variable, and the variables accounting for most of this variation were shore level and density. Body tissue and shell mass were negatively affected by increasing shore level and density. Shell length decreased with increasing shore level and increased with increasing pore water content. Reproductive effort was enhanced at high density.
\end{abstract}

KEY WORDS: Spatial heterogeneity $\cdot$ Macoma balthica $\cdot$ Density-dependence $\cdot$ Sediment $\cdot$ Shore level $\cdot$ Reproductive effort $\cdot$ Body mass $\cdot$ Shell

\section{INTRODUCTION}

Current ecological theories increasingly include spatial patterns of distribution as an important component of models (Legendre \& Fortin 1989, Legendre 1993). The spatial distribution pattern of a species represents a cumulative response of the population constituents to abiotic and biotic factors over time (Grant 1983, Olafsson et al. 1994). While species distribution and community organisation in intertidal rocky areas have been the subject of numerous studies (e.g. Connell 1961,

\footnotetext{
${ }^{*}$ Corresponding author. Present address: Vice-rectorat à la recherche, Université de Sherbrooke, Sherbrooke, Québec J1R 2R1, Canada. E-Mail: edwin.bourget@rectorat.usherb.ca
}

Menge 1991, Archambault \& Bourget 1996), softsediment intertidal areas have received less attention from ecologists (Peterson 1991, Olafsson et al. 1994). In these habitats, marine invertebrates show great variations in distribution and biomass (Woodin 1974, Thrush et al. 1989, Snelgrove \& Butman 1994, Turner et al. 1995), which appear to be determined largely by external factors (Peterson 1991, Snelgrove \& Butman 1994). Shore elevation (Bertness \& Grosholz 1985, Peterson \& Black 1987, Beukema \& Flach 1995), as a factor influencing food availability (Beukema et al. 1977, Peterson \& Black 1987) and physiological stress (Peterson \& Black 1988, Peterson 1991), water temperature (Beukema et al. 1985) and sediment grain size (McLusky \& Elliott 1981, Beukema \& Flach 1995) have been reported to be key variables. The latter factor has been 
shown to influence the distribution of deposit- and suspension-feeders (Rhoads \& Young 1970, Levinton 1972). Apart from abiotic factors, biological interactions such as predation (Holland et al. 1980) and intraspecific and interspecific competition (Woodin 1974, Levin 1981, Beukema \& Flach 1995) also influence distribution and biomass in soft-bottom intertidal populations. Moreover, the intensity and the type of biological interactions vary with the feeding mode (e.g. depositor suspension-feeding) of the animals (Levinton 1972). However, the relative influence of abiotic factors and of biological interactions on demographic response variables (e.g. density, biomass) of soft-bottom invertebrate communities is still not well understood.

Macoma balthica was selected in this study as a model species to study the influence of environmental factors on demographic and biotic response variables. This bivalve is a dominant species of temperate and cold-water soft-bottom communities (Thorson 1957, McLusky \& Elliott 1981), where it colonises littoral and infralittoral zones in different regions of the Northern Hemisphere. Its longevity is variable: $3 \mathrm{yr}$ in the Northern Baltic (Ankar 1980), 6 yr (Harvey \& Vincent 1990) and 12 yr (Lavoie et al. 1968) in the St. Lawrence Estuary, and $30 \mathrm{yr}$ in the Gulf of Finland (Segerstråle 1960). Its growth and reproduction seasons vary among regions. In the St. Lawrence Estuary this species grows between May and November (Harvey \& Vincent 1990) and reproduces once, approximately at the end of May (Harvey \& Vincent 1989). M. balthica uses both deposit- and suspension-feeding modes (Brafield \& Newell 1961, Bubnova 1972), and exhibits density-dependent growth under high density in descriptive (Vincent at al. 1994) and experimental (Olafsson 1986, Vincent et al. 1989) studies. Furthermore, its abundance in the St. Lawrence Estuary and its broad distribution in the Atlantic (Beukema \& Meehan 1985) and the Pacific (Nichols \& Thompson 1982), make it readily available and allow comparisons of results. The main objectives of this study were to assess, at the scale of a bay, the spatial variability in biotic variables (density, biomass, reproductive effort, shell length and growth), and examine their relationship to abiotic factors (sediment characteristics and immersion time) and to density. To our knowledge, this is the first study of this nature conducted on soft-sediment bi- valves to examine, over an entire bay and using an intense systematic sampling, the structure of several biotic variables in a $M$. balthica population and their relationship to several environmental factors concurrently.

\section{MATERIALS AND METHODS}

Study site. This study was conducted at 'Anse à

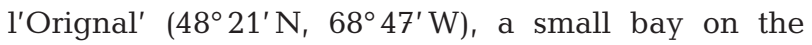
south shore of the lower St. Lawrence Estuary. The site is characterised by a semi-diurnal tide (max. amplitude: $4.6 \mathrm{~m}$ ). The bay is approximately $2 \mathrm{~km}$ wide and $1 \mathrm{~km}$ long, and becomes exposed over a distance of $800 \mathrm{~m}$ at spring tide. Water temperature varies from $-1.5^{\circ} \mathrm{C}$ in winter to about $13^{\circ} \mathrm{C}$ in summer. The whole intertidal zone is covered by ice (max. thickness about $1.5 \mathrm{~m}$ ) from mid-December to the end of March. The low-shore levels are characterised by homogeneous sandy sediment while high levels are more heterogeneous and dominated by muddy-gravelly sediment. The upper zone on the eastern side of the bay is covered by abundant Spartina sp. (see Fig. 1). The main

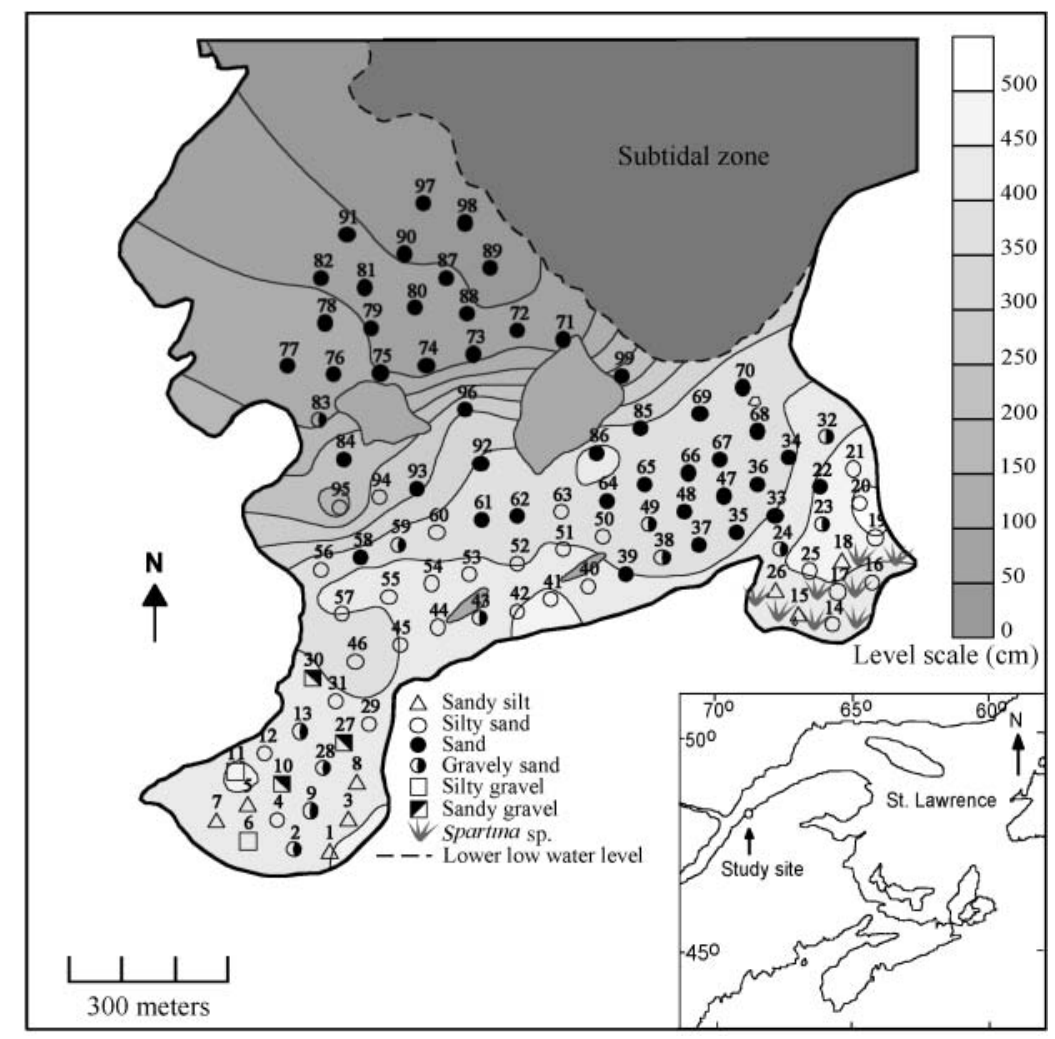

Fig. 1. Anse à l'Orignal, St. Lawrence Estuary. Station locations, sediment categories and interpolated contour surfaces of tidal level. The site coordinates and the mean values of all variables measured have been mapped. A contour map of tidal levels was produced by kriging, and specific symbols were assigned to sediment classes. Computations used the SURFER program for spatial analysis (Golden Software Inc. 1996) 
invertebrate species found in this bay are Macoma balthica, Mya arenaria, Nephtys caeca, Nereis virens, Littorina saxatilis, L. obtusata and Hydrobia totteni.

Sampling method and data acquisition. Sampling was carried out at low tide in May 1993, before reproduction, following a systematic sampling grid of 99 stations covering a surface area of $1.5 \mathrm{~km}^{2}$ (see Fig. 1).

Abiotic variables. We focused on intertidal level and sediment characteristics known to substantially influence local variation in abundance of Macoma balthica. The intertidal level of each station was measured (precision to $\pm 2 \mathrm{~cm}$ ) using a theodolite. Values were calibrated against the low-water level given by the tide tables (Department of Fisheries and Oceans, Canada, 1993). Sediment cores $2 \mathrm{~cm}$ in depth (the zone colonised by $M$. balthica) were collected with a circular corer (surface $\left.=24 \mathrm{~cm}^{2}\right)$ at each station $(\mathrm{n}=99$ samples $)$ and stored in the laboratory at $-20^{\circ} \mathrm{C}$ for later analysis of particle size distributions. Sediment composition was measured by standard wet-sieving of each sample (Folk 1974) and expressed, following the Wentworth size class, as percentage of gravel (phi $<-1)$, sand $(-1<$ phi $<4)$, silt $(4<$ phi $<8$ ) and clay (phi $>8$ ) content. Sediment category percentages were used in statistical analyses. The sediment was also classified into 6 types according to the dominant size class percentages (sandy silt, silty sand, sand, gravely sand, silty gravel, sandy gravel) and used in mapping to better visualise sediment distribution. Sediment water and organic matter contents were obtained by drying during $12 \mathrm{~h}$, at $75^{\circ} \mathrm{C}$ and at $450^{\circ} \mathrm{C}$ respectively and weighing (Mettler PC 2000 balance, $\pm 0.005 \mathrm{mg}$ ) sediment samples. Sediment water and organic matter contents were expressed as percentages.

Biotic variables. At each station, sediments in quadrats $(30 \times 30 \mathrm{~cm})$ were dug out to a depth of 8 to $10 \mathrm{~cm}$ and sieved through a $1 \mathrm{~mm}$ mesh. All animals collected were kept in clean estuarine water for $24 \mathrm{~h}$ to rid the gut of any food or sediment material. Samples were frozen at $-80^{\circ} \mathrm{C}$. Variables examined were density, reproductive effort, flesh and shell body mass, total length and shell growth. Macoma balthica was observed at all stations but 2. For measurements of reproductive effort and shell growth only, stations where the number of individuals was too low were submitted to a second collecting. Adult density was obtained by counting all individuals of $M$. balthica in each of the initial samples ( $\mathrm{n}=99$ stations), expressed as number of individuals per $\mathrm{m}^{2}$. Reproductive effort was measured on samples of 20 individuals randomly selected among all mature individuals (> $6 \mathrm{~mm}$ according to Harvey \& Vincent 1989) for each station where M. balthica occurred. For each individual, visceral mass was separated from the shell, and gonad material was removed from the flesh mass under a dissecting microscope $(\times 60)$. Shell, flesh and gonads were dried at constant temperature of $60^{\circ} \mathrm{C}$ during $24 \mathrm{~h}$ and weighed (Mettler M5SA micro-balance, $\pm 0.001 \mathrm{mg}$ ). Reproductive effort was obtained by dividing individual gonad mass by individual flesh mass (excluding gonad mass). Growth was measured on additional samples of 25 randomly selected individuals (growth samples) at each station where the number of individuals was sufficient ( $\mathrm{n}=77$ stations). Shell growth was estimated for the last growth season (see Ricker 1958, Kaufmann 1981). For each individual, 2 measurements (to the nearest $0.02 \mathrm{~mm}$ under a dissecting microscope with an ocular micrometer) were made: total length (longest distance between the anterior and the posterior margins of the most recently deposited annual shell growth mark) and length at the end of the preceding growing season. In the St. Lawrence estuary, these are always clearly marked by a narrow, dark year-ring (Lavoie et al. 1968, Vincent et al. 1987). Total length $\left(L_{t+1}\right)$ was plotted against length at the end of the preceding growing season $\left(L_{t}\right)$ to use the slope of the Ford-Walford regression $L_{t+1}=L_{\propto}(1-k)+k L_{t}$ (Ricker 1958, Green 1979). Here, shell growth rate $(k)$ is defined as the slope of this equation, $k\left(=\mathrm{e}^{-K}\right)$, where $K$ is the Brody's growth coefficient. The slope was then computed from each station. In addition, last summer new growth, detected by the appearance of a thinopaque white margin of newly formed material along the edge of the shell (Beukema et al. 1985, Harvey \& Vincent 1990), was measured on all individuals when observed. The number of individuals showing new growth within a given sample was expressed as a percentage of total number of individuals in the sample (Beukema et al. 1985). Shells of all individuals used in the growth sample were also dried at a constant temperature of $60^{\circ} \mathrm{C}$ for $24 \mathrm{~h}$ and weighed with a Mettler M5SA micro-balance with a precision of $\pm 0.001 \mathrm{mg}$. All gonad dissections and measurements of growth were carried out by the same person for uniformity. Flesh mass obtained from reproductive effort samples was computed as body tissue mass (excluding gonad mass). Shell mass was obtained from reproductive effort and growth samples, and total length $( \pm 0.02 \mathrm{~mm})$ was measured on all individuals collected. Environmental variables are considered as explanatory variables and other variables as response variables. Density is also considered as an explanatory variable in some cases.

Data analysis. Redundancy analysis (RDA; Rao 1964, Wollenberg 1977), the canonical form of principal component analysis (see Jongman et al. 1995) which combines the techniques of ordination and multiple regression (see Legendre \& Legendre 1998) was used to determine whether variations in response variables (density, flesh and shell mass, mean length, reproductive effort, shell growth rate [Ford's growth coefficient] 
and \% of new growth) were related to abiotic variables and density. Forward selection of abiotic variables (tidal level, organic matter and water content, gravel, sand, silt and clay percentages) was used to obtain a subset of abiotic variables maximally related to biotic variables (Jongman et al. 1995, Legendre \& Legendre 1998). The variable 'silt' was removed from the RDA to avoid collinearity among sediment class percentages. Monte Carlo permutation tests (Fisher 1935, Manly 1997) were carried out to test the significance of the relationships. All tests were performed with 999 permutations. Only stations with growth measurements were considered; thus 77 samples were used in this analysis. RDA, Monte Carlo permutation test and forward selection were carried out with the CANOCO 4.0 program (ter Braak \& Smilauer 1998).

Stepwise regressions were used to determine which environmental variables best accounted for the variance in the response variables (Legendre \& Legendre 1998). Bivariate scatterplots of all variables were drawn to evaluate the need for data transformation (Sokal \& Rohlf 1995). Normality was tested on residuals of the multiple regression (Shapiro-Wilk test). Variables were transformed when necessary. The variables selection procedure used the stepwise option from the STEPDISC procedure within the SAS software (SAS Institute Inc. 1988). A significance threshold of $5 \%$ was used. Only multivariate analyses were used in order to avoid confounding effects. The use of simple regressions with RDA and multiple regression could at best lead to redundant results.

\section{RESULTS}

\begin{abstract}
Abiotic variables
Organic matter content varied from 0 to $10.6 \%$ $(\bar{x}=2.18 \%, \mathrm{SD}=1.40 \%)$, and water content from 12.3 to $51.1 \%(\bar{x}=24.40 \%, \mathrm{SD}=6.19 \%)$. Mean organic matter values were generally greater at stations located at high level than those at low tidal level. The former stations also presented the greatest variation of water content values.
\end{abstract}

\section{Altitude}

The height of the sampling sites varied from 0 to $5.1 \mathrm{~m}$ above zero level (Fig. 1). In general, station height decreased from the south to the north of the bay, where it varied most. In the middle portion of the bay, station height approached the average value $(\bar{x}=3.37 \mathrm{~m}$, $\mathrm{SD}=1.42 \mathrm{~m}$ ). This portion is an area of rapid transition from relatively elevated to relatively low shore levels.
Sediment characteristics

The distribution of sediment types is shown in Fig. 1. The upper western and eastern zones were very heterogeneous, all sediment classes were represented. Silty sediments dominated the middle portion of the bay, while the eastern part and the lowest northern zone were generally dominated by sand.

\section{Biotic variables}

\section{Density}

Density ranged from 0 ind. $\mathrm{m}^{-2}$ at Stns 11 and 26, to 2700 ind. $\mathrm{m}^{-2}$ at Stn 32 . Density averaged 835 ind. $\mathrm{m}^{-2}$ over the 99 stations (Fig. 2a). High values were observed near the mean and low-water levels, while low density values were observed at the upper levels where stations with gravelly sediments or Spartina sp. were numerous. Densities were also more variable in the middle of the bay.

\section{Body tissue and shell mass}

The average body tissue mass per station ranged from $1.76 \mathrm{mg}$ (Stn 27) to $19.12 \mathrm{mg}$ (Stn 98) $(\bar{x}=$ $7.07 \mathrm{mg})$, while shell mass ranged from $25.96 \mathrm{mg}$ (Stn 27) to $266.53 \mathrm{mg}$ (Stn 98) $(\bar{x}=110.33 \mathrm{mg})$ (Fig. 2b,c). Body tissue and shell mass showed similar distributions, with greater variability in the middle zone (where the shore level and sediment were heterogeneous) and higher mass in the northern zone (low level and sandy sediment). Stations with high density values appeared to show low body tissue mass and shell mass and vice versa (e.g. Stns 1 and 32) (see subsection 'Influence of density and abiotic variables on response variables' for detailed analysis).

\section{Index of reproductive effort}

The mean index of reproductive effort (individual gonad:flesh mass ratio) did not vary much compared to the other variables (Fig. 2d). The mean gonad: flesh mass ratio ranged from 0.26 at Stn 17 to 1.54 at Stn 50 $(\bar{x}=0.93)$. Greatest variation was observed in the upper and the middle parts of the bay, where the extreme values were reached. There was no apparent relationship between index of reproductive effort and environmental variables. However, stations with high density values exhibited a high gonad:flesh mass ratio, e.g. Stns 50 and 63. This relationship was more evident in the middle part of the bay. The most homogeneous dis- 


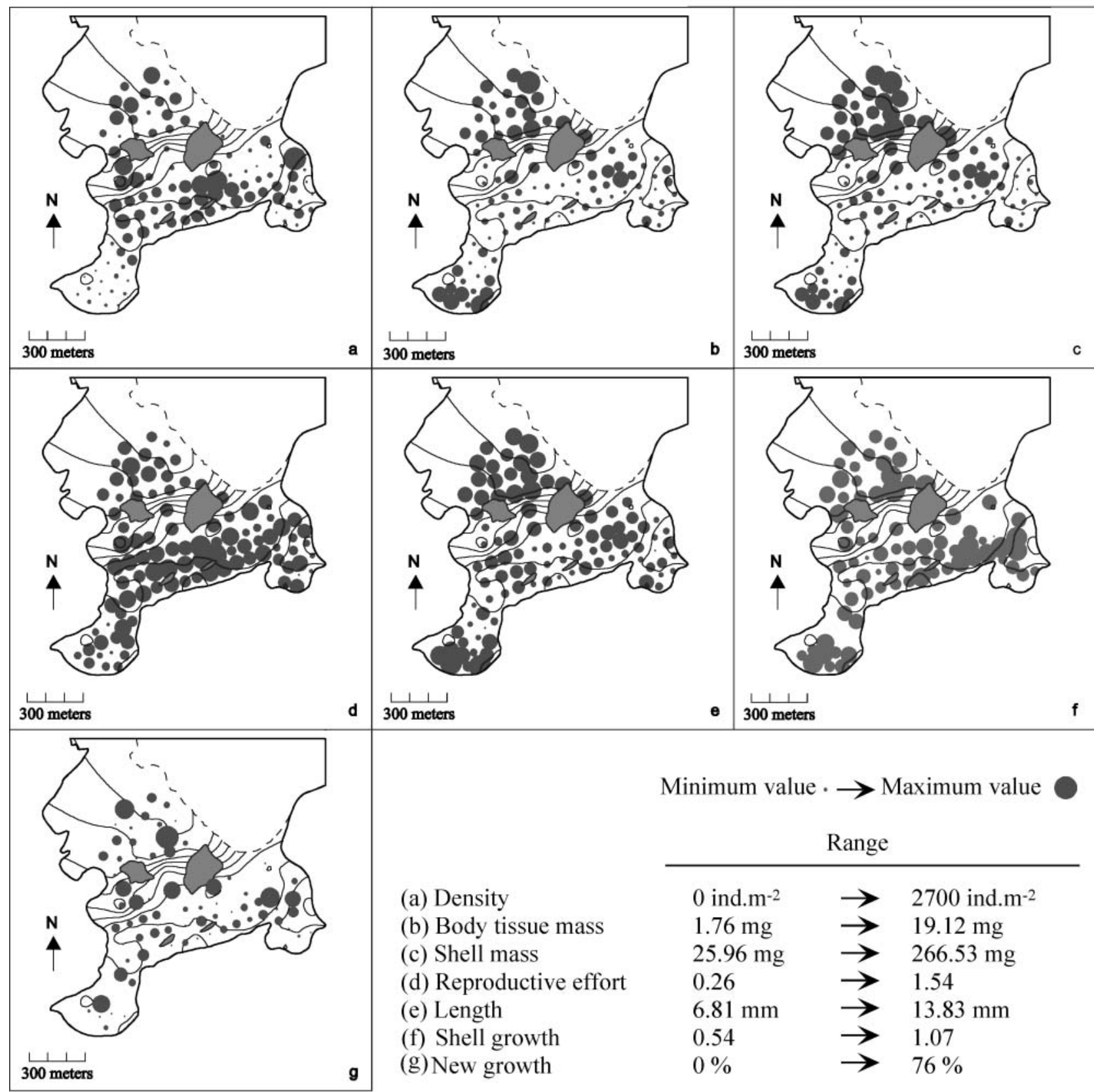

Fig. 2. Macoma balthica. Distribution patterns of response variables in the population at Anse-à-l'Orignal. Symbol size is linearly proportional to the variable value (see Fig. 1 legend for detailed method). Mean $\left( \pm \mathrm{SD}\right.$ ) values were: (a) density 835.02 (ind. $\mathrm{m}^{-2}$ ) $( \pm 610.48)_{\text {; }}$ (b) body tissue mass $7.07 \mathrm{mg}( \pm 3.59)_{\text {; }}$ (c) shell mass $110.33 \mathrm{mg}( \pm 58.21)_{\text {; }}(\mathrm{d})$ reproductive effort (gonad:flesh mass ratio) $0.93( \pm 0.25) ;$ (e) length $10.10 \mathrm{~mm}( \pm 1.52)$; (f) shell growth (Ford's growth coefficient $k) 0.85$ ( \pm 0.10$)$; $(\mathrm{g})$ new growth (\% individuals), $18.33 \%( \pm 18.50)$. Station positions as in Fig. 1

tribution of the index was observed in the western middle part, which was also characterised by high variability in both sediment and height. Hence, the variable which would probably be related to reproductive effort is density (see below subsection 'Influence of environmental variables on response variables').

\section{Shell length}

Mean shell length ranged from 6.81 to $13.83 \mathrm{~mm}$ $(\bar{x}=10.10 \mathrm{~mm})$ and showed large variations in the middle and upper parts of the bay (max: $13.83 \mathrm{~mm}$ at Stn 1; min: $6.81 \mathrm{~mm}$ at Stn 23). In general, in the lower zone, 
values were uniformly high (Fig. 2e). Length distribution followed that of body tissue and shell mass, and was roughly inverse to density distribution. High values also appeared to be related to sandy sediments (see later subsection).

Shell growth and percentage of individuals exhibiting new growth

Shell growth rate (Ford's growth coefficient) ranged from 0.54 at Stn 36 to 1.07 at Stn 23. The extreme values were reached in the middle and the upper parts, where some variability was observed (Fig. 2f), but generally, relatively homogeneous values were observed across the whole area.

The percentage of individuals exhibiting new growth ranged from 0 (at $27 \%$ of the stations) to $76 \%$ at Stn $88(\bar{x}=18.33 \%$; Fig. 2g). No spatial trend could be detected.

\section{Abiotic factors influencing biotic variables}

The results of the redundancy analyses for the biotic variables constrained by the abiotic variables were used to generate an ordination biplot (Fig. 3). To avoid multicollinearity between abiotic variables, the variable 'silt' was removed from the model. Thus, 3 of the 4 sediment variables were used in the analysis. Since 6 explanatory variables (abiotic factors) were used, the first 6 axes were canonical. The percentage of total variance explained by the analysis was 31.5 , with Axis 1 alone accounting for $25 \%$ of the total variance

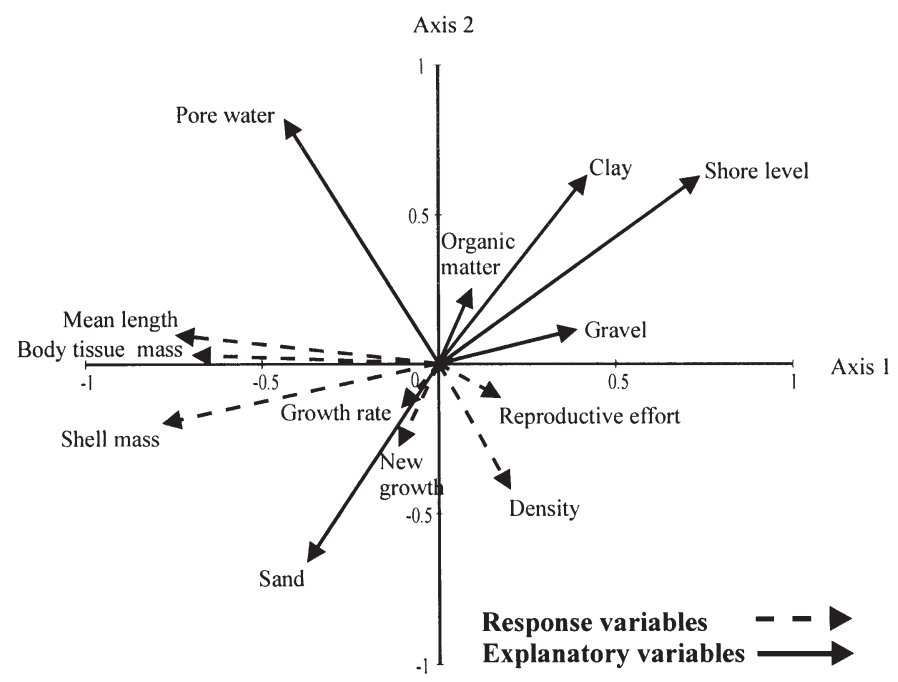

Fig. 3. Macoma balthica. Redundancy analysis ordination biplot of biotic and abiotic variables
( $p<0.001)$. Correlations of the explanatory variables with the axes suggest that Axis 1 represented the shore level axis (Table 1). Axis 2, a pore water axis (pore water was the variable correlating most to this axis), accounted for only $4 \%$ of the total variance (Table 1 ). In RDA, a positive correlation is expressed by relatively long vectors roughly pointing in the same direction and a negative correlation is indicated by arrows pointing in opposite directions. Perpendicular arrows indicate that there is no correlation. The biplot (Fig. 3) shows that mean shell length and mass and body tissue showed the greatest variations and differed from density and reproductive effort in their response to abiotic variables. Mean shell length and mass, and body tissue mass were negatively affected by shore level and percentage clay and gravel. In contrast, sand and pore water influenced positively mean shell length and mass, and body tissue. The position of the density vector suggests that this variable was mainly under the positive influence of sand and the negative influence of pore water. The proportion of individuals showing new growth, shell growth rate and reproductive effort did not contribute much to Axes 1 and 2 and therefore were only weakly related to abiotic variables.

\section{Influence of environmental variables on response variables}

Of the total variation in response variables (body tissue and shell mass, mean length, shell growth, \% of individuals exhibiting new growth and reproductive effort) $12 \%$ ( $\mathrm{p}<0.001$ ) were explained by Axis 1 and thus by density, since it is the single explanatory variable (Fig. 4). Fig. 4 also shows that both body tissue mass and mean total length are reduced when density increases. Shell mass was also negatively affected by density, but less strongly than body tissue and mean shell length. Reproductive effort was positively affected by density and, finally, shell growth and percentage of individuals exhibiting new growth did not contribute to Axes 1 and 2 and therefore the variance of these response variables was likely not accounted for by density.

Results of the multiple regression of selected biotic variables on abiotic variables and density are shown in Table 2. Only variables retained by the stepwise procedure are presented. Percentage of sand alone accounted for the greatest fraction $(20 \%)$ of total variance in density, while silt, shore level and \% gravel explained together $18 \%(8,4$ and $6 \%$ respectively) of the variance (Table 2a). Density increased with increasing sand, silt and gravel, but decreased with increasing shore level. Shore level, density and pore water influenced body mass variation (Table $2 b$ ). Shore level and density were the most important variables affecting 
body tissue mass. Together these variables accounted for $47 \%$ of the variance in body tissue mass ( 25 and $22 \%$ respectively) while pore water accounted for $10 \%$ of the total variance in body tissue mass Shore level alone accounted for $51 \%$ of the total variance in shell mass (Table 2c), while density and pore water content together accounted for $16 \%$ (11 and 5\% respectively). Shell mass decreased with increasing shore level and density, and increased with increasing pore water content (Table 2c). Only 1 variable significantly accounted for reproductive effort. Indeed, $11 \%$ of the total variance in reproductive effort was accounted for by density, and reproductive effort increased when density increased (Table 2d). Shore level and pore water accounted for $49 \%$ of the total variance in mean shell length, and density only a further $7 \%$ (Table $2 \mathrm{e}$ ). Both

Table 1. Results of redundancy analysis using abiotic variables as explanatory variables. Significance values of the two canonical axes and of all canonical axes are $p=0.001$, estimated by Monte Carlo test after 999 permutations

\begin{tabular}{|c|c|c|}
\hline & Axis 1 & Axis 2 \\
\hline \multicolumn{3}{|c|}{ Correlations of abiotic variables with first 2 axes } \\
\hline Level & 0.55 & 0.34 \\
\hline Water & -0.33 & 0.44 \\
\hline Organic matter & 0.07 & 0.16 \\
\hline Gravel & 0.29 & 0.05 \\
\hline Sand & -0.28 & -0.37 \\
\hline Clay & 0.31 & 0.37 \\
\hline Eigenvalues $^{\mathrm{a}}$ & 0.25 & 0.04 \\
\hline \multicolumn{3}{|c|}{$\begin{array}{l}{ }^{a} \text { Proportion of the variation of the biotic variables } \\
\text { explained by the abiotic variables }\end{array}$} \\
\hline
\end{tabular}

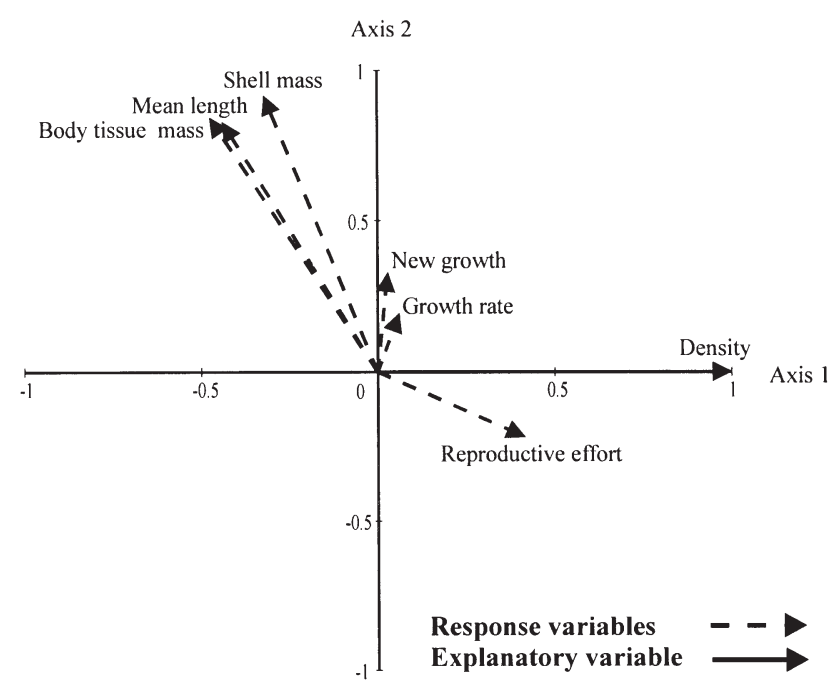

Fig. 4. Macoma balthica. Redundancy analysis ordination biplot of biotic response variables and density as explanatory variable. level and density had a negative effect on mean shell length, while water content had a positive effect. Finally, none of the variables introduced in the analyses significantly accounted for shell growth rate (Ford's growth coefficient) nor for percentage individuals showing new growth. This could be due to the low variation exhibited by the slope and by the number of zero values in new growth variable.

Table 2. Results of stepwise procedure. Only variables retained by the stepwise procedure are presented. All variables left in the model are significant at the 0.05 level

(a) Density as dependent variable. Density square roottransformed, sand and silt expressed as inverse (1/sand, 1/silt), gravel ln-transformed (lngravel) (intercept $=53.72 ; R^{2}$ for model $=0.3804$ )

\begin{tabular}{lrclc} 
& $1 /$ sand & $1 /$ silt & level & lngravel \\
\hline Partial r $^{2}$ & 0.2009 & 0.0763 & 0.0426 & 0.0605 \\
Probability & 0.0001 & 0.0020 & 0.0065 & 0.0032 \\
Regression & -799.49 & -18.66 & -0.03 & 0.74 \\
coefficients & & & &
\end{tabular}

(b) Body tissue mass as dependent variable (intercept = 9.67; $\mathrm{r}^{2}$ for model $=0.5771$ )

\begin{tabular}{llll} 
& Level & Density & Water \\
\hline Partial r $^{2}$ & 0.2476 & 0.2249 & 0.1046 \\
Probability & 0.0001 & 0.0001 & 0.0001 \\
Regression & -0.02 & -0.00 & 0.20 \\
coefficients & & &
\end{tabular}

(c) Shell mass as dependent variable (intercept $=191.06$; $\mathrm{r}^{2}$ for model $=0.6629$ )

\begin{tabular}{llll} 
& Level & Density & Water \\
\hline Partial $\mathrm{r}^{2}$ & 0.5064 & 0.1084 & 0.0481 \\
Probability & 0.0001 & 0.0001 & 0.0004 \\
$\begin{array}{l}\text { Regression } \\
\text { coefficients }\end{array}$ & -0.34 & -0.03 & 2.23
\end{tabular}

(d) Ratio gonad mass to flesh mass (reproductive effort) as dependent variable (intercept $=0.81 ; \mathrm{r}^{2}$ for model $=$ 0.1081)

\begin{tabular}{ll} 
& Density \\
\hline Partial $\mathrm{r}^{2}$ & 0.1081 \\
Probability & 0.0010 \\
Regression & +0.00 \\
coefficient &
\end{tabular}

(e) Mean shell length as dependent variable (intercept $=$ $10.43 ; r^{2}$ for model $=0.5612$ )

\begin{tabular}{llll} 
& Level & Water & Density \\
\hline Partial r ${ }^{2}$ & 0.2389 & 0.2528 & 0.0695 \\
Probability & 0.0001 & 0.0001 & 0.0002 \\
Regression & -0.01 & 0.11 & -0.00 \\
coefficients & & & \\
\hline
\end{tabular}




\section{DISCUSSION}

\section{Tidal level and sediment characteristics}

Tidal level and sediment characteristics were very heterogeneous, and sediment type distribution was similar to that previously observed at Anse à l'Orignal' by Harvey \& Vincent (1991), and Vincent et al. (1994).

\section{Density}

In our study, Macoma balthica density varied highly (Fig. 2a), as observed elsewhere (McErlean 1964, Newell 1965, Myren \& Pella 1977, McLusky \& Elliott 1981, Müller-Haeckel \& Müller 1982, Cranford et al. 1985). The density values observed were inside the large range of values ( 0 to 4000 ind. $\mathrm{m}^{-2}$ ) previously observed in the St. Lawrence Estuary (Vincent et al. 1987, 1989, 1994, Harvey \& Vincent 1989, 1990, 1991, Harvey et al. 1993), and were comparable to or higher than the maximum values previously observed by Vincent et al. (1989, 1994) at Anse à l'Orignal. Density exhibited the largest variation at mean tidal level, where the highest values were found. This was also observed by Vincent et al. $(1989,1994)$ at Anse à l'Orignal, and by Beukema et al. (1977), Reading (1979), McLusky \& Elliott (1981) on the eastern Atlantic coasts. However, some authors showed that the highest densities were located in the upper parts of the intertidal area (in the St. Lawrence Estuary: at Baie des Roses by Vincent et al. 1987 and Harvey \& Vincent 1990 and at various locations by Harvey \& Vincent 1991; in Hudson Bay: Green 1973; in the Bay of Fundy: Risk \& Moffat 1977, Cranford et al. 1985; along the European coasts: Ratcliffe et al. 1981). In our study, the variation in density is principally related to sediment type, as seen in the redundancy analysis and multiple regressions (Fig. 3, Table 2a). Density relates positively to sand content, less to silt and gravel content, and negatively to tidal level and pore water content. Indeed, distribution maps confirm that density follows sediment type distribution more than tidal level (Figs. 1 \& 2a). High densities at low tidal levels were observed in sandy sediment, while the high variability observed in the middle of the bay is probably related to sediment type variability. However low densities at the upper levels could also be linked to the presence of Spartina sp. In agreement with our results, Reading (1979) indicated the preference of $M$. balthica for sandy sediments, while Newell (1965), Tunnicliffe \& Risk (1977), McLusky \& Elliott (1981) and Olafsson (1986) observed highest densities of $M$. balthica in fine sediments. Myren \& Pella (1977) and Vincent et al. (1987) related the distribution of M. balthica to tidal level, but Vincent et al. (1994) did not find any relationship between density and abiotic variables. These differences among authors could be related to differences in sampling coverage, particularly in the upper part of the intertidal, and by the fact that sediment type was sometimes not considered. $M$. balthica distribution has also been related to the organic matter content of the sediment (Newell 1965, Bubnova 1972, McLusky \& Elliott 1981, Madsen \& Jensen 1987) and by sediment water content (Turk et al. 1980). In our study, RDA and multiple regression did not reveal any influence of organic matter content on density distribution (Fig. 3, Table 2a). Besides these various abiotic factors, sediment bacteria (Tunnicliffe \& Risk 1977), salinity (Müller-Haeckel \& Müller 1982), sediment stability (Cranford et al. 1985), mortality (Lammens 1967, Cranford et al. 1985), predation, parasitism (Beukema 1993), and larval settlement (Cranford et al. 1985, Armonies \& Hellwig-Armonies 1992, Beukema 1993) could also affect adult distribution patterns.

\section{Body tissue mass and shell mass}

The relationship of body tissue and shell mass with both density and tidal level has been demonstrated by multiple regression and redundancy analyses (Figs. 3 $\& 4$, Table $2 \mathrm{~b}, \mathrm{c}$ ) which highlight also the positive effect of pore water content on these variables.

In bivalves, a decrease in somatic production is a common response to unfavourable conditions (Thompson 1979, Kautsky 1982, MacDonald \& Thompson 1985). Food depletion has been identified as the most important factor affecting body mass. This factor is linked to both immersion duration (Chambers \& Milne 1975, Griffiths 1981b, Harvey \& Vincent 1989, 1991, Franz 1993, 1997) and high density (Peterson 1982, Jensen 1993).

Intraspecific competition effects are comparable to immersion time effects on body tissue mass, whereas, according to Peterson (1982) and Jensen (1993), the latter factor showed more influence on body tissue mass. In contrast to the observations of Franz (1993), who found that tidal level had more effect on flesh mass than on shell mass, our observations show that tidal level is by far the most important variable affecting shell mass, suggesting that shell mass is mostly under long-term influence of tidal level, while body tissue mass is apparently more 'plastic' and may vary as a function of factors exhibiting short- and long-term variations (here density and tidal level). However, the results from various studies are not easy to compare, since flesh values presented in numerous studies included gonad mass, or some studies examined few effects (e.g. local density linked to shore level or to sediment characteristics). 


\section{Index of reproductive effort}

The gonad:flesh mass ratio (hereafter called 'reproductive effort') was greater in the middle intertidal zone, but was more variable in the upper intertidal, where the extreme values were observed (Figs. 1 \& 2d). However, reproductive effort varied little compared to other variables. Compared to values observed by Harvey \& Vincent (1989) at Baie des Roses, close to Anse à l'Orignal (from a ratio of 0.27 at the lower level to 0.07 at the upper level), and with comparable environmental characteristics, the values observed in our study were very high (from 0.26 to 1.54 for the whole area). Indeed, the low values observed at high levels were either equal to or greater than the highest values observed at low levels by Harvey \& Vincent (1989). However, their low results may be related to a low variation in reproductive effort (gonad:flesh mass ratio), which they examined for only 1 shell size class $(8.5 \mathrm{~mm})$ and at only 2 tidal levels. In our study, reproductive effort broadly followed density distribution (Fig. 2a,d), i.e. stations with high density exhibit a high reproductive effort, except in the upper intertidal zone where the relationship was less evident. Indeed, statistical analyses revealed a positive relationship between reproductive effort and density (Figs. $3 \&$ 4, Table 2d). In some invertebrates, increased reproductive effort has been shown in response to stressful conditions, particularly low food availability (sea urchins: Thompson 1982; bivalves: Bayne et al. 1978, 1983, Griffiths 1981a,b, Thompson 1984, MacDonald \& Thompson 1986, Franz 1997).

In our study, density negatively affected body tissue mass and gonad mass ( $r=-0.24, p<0.005)$. Macoma balthica individuals at high density allocate less energy to maintain flesh than gonad. Enhanced reproductive effort has already been related to age and size structure variability. This variability was observed by Vincent et al. (1987) and Harvey \& Vincent (1990) at Baie des Roses. With increasing age and size, there is a shift in the allocation of available energy from somatic and shell growth to gamete production (Thompson 1979, 1984, Kautsky 1982, Vincent et al. 1989, Harvey \& Vincent 1991, Harvey et al. 1993). However, in our study, reproductive effort was not positively linked to shell size. Indeed, the relationship was negative and very weak $(r=-0.23$, $\mathrm{p}<0.05$ ). Thus, only age could have a possible influence on reproductive effort. The spatial distribution pattern also suggests a link between reproductive effort and tidal level (Figs. 1 \& 2d), but no statistically significant relationship was observed in our study. However, Harvey \& Vincent (1989) showed a negative effect of tidal level when they used gonad mass. We have also observed a negative relationship between tidal level and gonad mass $(\mathrm{r}=-0.54$, $\mathrm{p}<0.001$ ), while there was no relationship with reproductive effort. However, the results of Harvey \& Vincent $(1989,1991)$ showed that at high densities in the upper tidal levels, the larger individuals displayed low sexual production, no shell growth, and a flesh mass loss, which could result in increasing reproductive effort if the latter were expressed as gonad:flesh mass ratio. Comparison among studies dealing with reproductive effort should be made with caution, since varying ways of estimating reproductive effort (e.g. relative versus absolute gonad production), and individual sizes examined may lead to apparently divergent results.

\section{Shell length}

The maximum shell length of Macoma balthica observed in various regions of the western North Atlantic coasts (McErlean 1964: 32 mm; Gilbert 1973: $26 \mathrm{~mm}$; Commito 1982: $25 \mathrm{~mm}$ ) or of the eastern North Atlantic coasts (Evans \& Tallmark 1977: 24 mm; Reading 1979: 23 mm; Bachelet 1980: 19 mm) shows a wide range of values. In the St. Lawrence Estuary, Lavoie et al. (1968) observed smaller maximum values than ours $(\sim 13 \mathrm{~mm})$, while Vincent et al. (1987) and Harvey \& Vincent (1990), observed comparable values $(\sim 18 \mathrm{~mm})$.

The greatest variability in mean length distribution was observed in the middle zone of the bay, and roughly followed body tissue and shell mass distributions (Figs. 2b,c,e). Pore-water content and tidal level were the main factors affecting shell length (Fig. 3, Table 2e). The negative effect of tidal level on length has been previously recorded for Macoma balthica (Reading 1979, Vincent et al. 1987, 1989, 1994, Harvey \& Vincent 1990, Wanink \& Zwarts 1993) and other bivalves (Griffiths 1981b, Jensen 1993). In our study, local density (as an explanatory variable) added little explanation to shore level effects (Figs. 3 \& 4, Table 2e), but in several studies strong effects of density on shell length of M. balthica (Vincent et al. 1989, 1994) and other bivalves (Peterson \& Andre 1980, Peterson 1982, Peterson \& Black 1987, Jensen 1993) were observed, with an intensified influence when shore height increased (Vincent et al. 1989).

The mean shell length distribution pattern observed in our study could be explained by a positive effect of pore water content, possibly through its temperature buffering capacity, or by a greater number of young individuals in the upper intertidal, as observed by Harvey \& Vincent (1990) at Baie des Roses. 


\section{Shell growth}

In our study, shell growth (Ford's growth coefficient) could not be related to any explanatory variable examined. Shell growth of Macoma balthica has been shown, however, to be related negatively to density (Olafsson 1986, Vincent et al. 1989, 1994), and positively to immersion time (Beukema et al. 1977, Vincent et al. 1987, 1989, 1994, Harvey \& Vincent 1990).

The proportion of individuals exhibiting new growth could not be related to any variable examined. Harvey \& Vincent (1990) and Harvey et al. (1993) related the higher percentage of individuals with newly grown material observed at the upper level, to an earlier beginning of growth, possibly induced by optimal sediment temperatures (between 4 and $16^{\circ} \mathrm{C}$ ) during spring.

In our study, population density was not affected by the same abiotic variables as individual variables, i.e. reproductive effort, body tissue mass, shell mass and length. Contrary to previous studies in the same area (Vincent et al. 1987, 1994), our results showed a relationship between population density and sediment. Sediment is generally related to hydrodynamics. Postlarval settlement has also been shown to be related to sediment (see Butman 1987, Armonies \& HellwigHarmonies 1992, Ahn et al. 1993). This suggests that sediment controls the spatial distribution pattern of adults through post-larval settlement and/or survival, but this was not examined in our study. However, spatial distribution could also be affected by the redistribution of juveniles (Beukema 1993, Armonies 1996) and by the migration and the mortality of adults (affected for example by ice scour and sediment instability: Cranford et al. 1985). Furthermore, in our study, a great fraction of the variance in adult density was unaccounted for, suggesting that complex processes or factors other than those examined here are implicated in the spatial density structure. Tidal level and density were the most important factors affecting biotic variables, with density accounting for a great part of the variance of all the variables. In agreement with many studies, shell mass and shell length were the most environment-dependent (tidal level and pore water) of the response variables measured while, in contrast to what is generally observed, reproductive effort was clearly density-dependent. Different parts of the bay showed different patterns of response of biotic variables to environmental factors, the lower parts of the bay being the most productive area, i.e. individuals in these parts exhibited elevated mass (in shell and body) and length even in high density situation. This suggests that the effects of density varied with the carrying capacity of the habitat, i.e. the effects were less strong in sites where the immersion rate was high (more time for feeding or greater qantity or quality of food) an/or when Macoma balthica used a suspension feeding mode (in exposed sandy areas; Olafsson 1986). Maps and multivariate analyses (used here with several environmental and biotic variables) suggested spatial variation in the interactions between these variables, and complexity of population regulation processes.

Acknowledgements. We thank C. Savoie, P. Lacasse and B. Côté for their assistance in the field and laboratory. L. Lapointe (GIROQ, Université Laval) provided statistical advice and J.-C. Brêthes (ISMER) financial support for granulometry analysis. LA is grateful to P. Legendre (Université de Montréal) for his hospitality in his laboratory, and to R. Joannette (Director of the Parc du Bic) for the authorisation to sample in the park. This research was supported by a FCAR grant to B. Vincent (Département de Biologie, Université du Québec à Rimouski)

\section{LITERATURE CITED}

Ahn IY, Lopez G, Malouf R (1993) Effects of the gem clam Gemma gemma on early post settlement emigration, growth and survival of the hard clam Mercenaria mercenaria. Mar Ecol Prog Ser 99:61-70

Ankar S (1980) Growth and production of Macoma balthica (L.) in a northern Baltic soft bottom. Ophelia (Suppl)1: $31-48$

Archambault P, Bourget E (1996) Scales of coastal heterogeneity and benthic intertidal species richness, diversity and abundance. Mar Ecol Prog Ser 136:111-121

Armonies W (1996) Changes in distribution patterns of 0 group bivalves in the Wadden Sea: byssus drifting releases juveniles from the constraints of hydrography. J Sea Res 35:323-334

Armonies W, Hellwig-Armonies AM (1992) Passive settlement of Macoma balthica spat on tidal flats of the Wadden Sea and subsequent migration of juveniles. Neth J Sea Res 29:371-378

Bachelet G (1980) Growth and recruitment of the tellinid bivalve Macoma balthica at the southern limit of its geographical distribution, the Gironde Estuary (SW France). Mar Biol 59:105-117

Bayne BL, Holland DL, Moore MN, Lowe DM, Widdows J (1978) Further studies on the effects of stress in the adult on the eggs of Mytilus edulis. J Mar Biol Assoc UK 58: 825-841

Bayne BL, Salkeld PN, Worrall CM (1983) Reproductive effort and value in different populations of the marine mussel, Mytilus edulis L. Oecologia 59:18-26

Bertness MD, Grosholz E (1985) Population dynamics of the ribbed mussel, Geukensia demissa: the cost and benefits of an aggregated distribution. Oecologia 67:192-204

Beukema JJ (1993) Successive changes in distribution patterns as an adaptive strategy in the bivalve Macoma balthica (L.) in the Wadden Sea. Helgol Meeresunters 47:287-304

Beukema JJ, Flach EC (1995) Factors controlling the upper and lower limits of the intertidal distribution of two Corophium species in the Wadden Sea. Mar Ecol Prog Ser 125:117-126

Beukema JJ, Meehan BW (1985) Latitudinal variation in 
linear growth and other shell characteristics of Macoma balthica. Mar Biol 90:27-33

Beukema JJ, Cadée GC, Jansen JJM (1977) Variability of growth rate of Macoma balthica (L.) in the Wadden Sea in relation to availability of food. In: Keegan BF, Ceidig PO, Boaden PJS (eds) Biology of benthic organisms. 11th Eur Mar Biol Symp. Pergamon Press, Oxford, p 69-77

Beukema JJ, Knol E, Cadée GC (1985) Effects of temperature on the length of the annual growing season in the tellinid bivalve Macoma balthica (L.) living on tidal flats in the Dutch Wadden Sea. J Exp Mar Biol Ecol 90:129-144

Brafield AE, Newell GE (1961) The behaviour of Macoma balthica (L.). J Mar Biol Assoc UK 41:81-87

Bubnova NP (1972) The nutrition of the detritus-feeding mollusks Macoma balthica (L.) and Portlandia arctica (Gray) and their influence on bottom sediments. Okeanologiya 12:899-905

Butman CA (1987) Larval settlement of soft sediment invertebrates: the spatial scales of pattern explained by active habitat selection and the emerging role of hydrodynamical processes. Oceanogr Mar Biol Annu Rev 25:113-165

Chambers MR, Milne H (1975) The production of Macoma balthica (L.) in the Ythan Estuary. Estuar Coast Mar Sci 3: 443-455

Commito JA (1982) Effects of Lunatia heros predation on the population dynamics of Mya arenaria and Macoma balthica in Maine, USA. Mar Biol 69:187-193

Connell JH (1961) The influence of interspecific competition and other factors on the distribution of the barnacle Chthamalus stellatus. Ecology 42:710-723

Cranford PJ, Peer DL, Gordon DC (1985) Population dynamics and production of Macoma balthica in Cumberland Basin and Shepody Bay, Bay of Fundy. Neth J Sea Res 19: 135-146

Department of Fisheries and Oceans, Canada (1993) Canadian tide and current tables. Department of Fisheries, Ottawa

Evans S, Tallmark B (1977) Growth and biomass of bivalve molluscs on a shallow, sandy bottom in Gullmar Fjord (Sweden). ZOON 5:33-38

Fisher RA (1935) The design of experiments. Oliver \& Boyd, Edinburgh

Folk RL (1974) Petrology of sedimentary rocks. Hemphill Publishing, Austin, TX

Franz DR (1993) Allometry of shell and body weight in relation to shore level in the intertidal bivalve Geukensia demissa (Bivalvia: Mytilidae). J Exp Mar Biol Ecol 174: 193-207

Franz DR (1997) Resource allocation in the intertidal saltmarsh mussel Geukensia demissa in relation to shore level. Estuaries 20:134-148

Gilbert MA (1973) Growth rate, longevity and maximum size of Macoma balthica (L.). Biol Bull 145:119-126

Golden Software (1996) Surfer ${ }^{\mathrm{TM}}$ for Windows Notes v.6. Copyright Golden Software Incorporated, Golden, CO

Grant J (1983) The relative magnitude of biological and physical sediment reworking in an intertidal community. J Mar Res 41:673-989

Green RH (1973) Growth and mortality in an arctic intertidal population of Macoma balthica (Pelecypoda, Tellinidae). J Fish Res Board Can 309:1345-1348

Green RH (1979) Sampling design and statistical methods for environmental biologists. John Wiley \& Sons, New York

Griffiths RJ (1981a) Population dynamics and growth of the bivalve Choromytilus meridionalis (Kr.) at different tidal levels. Estuar Coast Shelf Sci 12:101-118

Griffiths RJ (1981b) Production and energy flow in relation to age and shore level in the bivalve Choromytilus meridionalis (Kr.). Estuar Coast Shelf Sci 13:477-493

Harvey M, Vincent B (1989) Spatial and temporal variations of the reproduction cycle and energy allocation of the bivalve Macoma balthica (L.) on a tidal flat. J Exp Mar Biol Ecol 129:199-217

Harvey M, Vincent B (1990) Density, size distribution, energy allocation and seasonal variations in shell and soft tissue growth at two tidal levels of a Macoma balthica (L.) population. J Exp Mar Biol Ecol 142:151-168

Harvey M, Vincent B (1991) Spatial variability of length specific production in shell, somatic tissue and sexual products of Macoma balthica in the Lower St. Lawrence Estuary. 1. Small and meso scale variability. Mar Ecol Prog Ser 75:55-66

Harvey M, Vincent B, Gratton Y (1993) Spatial variability of length specific production in shell, somatic tissue and sexual products of Macoma balthica in the lower St. Lawrence Estuary. 2. Large scale variability. Mar Biol 115: 421-433

Holland AF, Mountford NK, Hiegel MH, Kaumeyer KR, Mihursky JA (1980) Influence of predation on infaunal abundance in upper Chesapeake Bay, USA. Mar Biol 57: 221-235

Jensen KT (1993) Density dependent growth in cockles (Cerastoderma edule): evidence from interannual comparisons. J Mar Biol Assoc UK 73:333-342

Jongman RHG, ter Braak CJF, van Tongeren OFR (1995) Data analysis in community and landscape ecology. Cambridge University Press, Cambridge

Kaufmann KW (1981) Fitting and using growth curves. Oecologia 49:293-299

Kautsky N (1982) Quantitative studies on gonad cycle, fecundity, reproductive output and recruitment in a Baltic Mytilus edulis population. Mar Biol 68:143-160

Lammens JJ (1967) Growth and reproduction in a tidal flat population of Macoma balthica (L.). Neth J Sea Res 3: $315-382$

Lavoie R, Tremblay JL, Filteau G (1968) Âge et croissance de Macoma balthica L. à Cacouna-Est dans l'estuaire du St-Laurent. Nat Can (Quebec) 95:887-895

Legendre P (1993) Spatial autocorrelation: trouble or new paradigm? Ecology 74:1659-1673

Legendre P, Fortin MJ (1989) Spatial pattern and ecological analysis. Vegetatio 80:107-138

Legendre P, Legendre L (1998) Numerical ecology. Developments in environmental modelling, Vol 20, 2nd English edn. Elsevier Science BV, Amsterdam

Levin LA (1981) Dispersion, feeding behavior and competition in two spionid polychaetes. J Mar Res 39:99-117

Levinton JS (1972) Stability and trophic structure in depositfeeding and suspension-feeding communities. Am Nat 106:472-486

Macdonald BA, Thompson RJ (1985) Influence of temperature and food availability on the ecological energetics of the giant scallop Placopecten magellanicus. I. Growth rates of shell and somatic tissue. Mar Ecol Prog Ser 25:279-294

Macdonald BA, Thompson RJ (1986) Production, dynamics and energy partitionning in two populations of the giant scallop Placopecten magellanicus (Gmelin). J Exp Mar Biol Ecol 101:285-299

Madsen PB, Jensen K (1987) Population dynamics of Macoma balthica in the Danish Wadden Sea in an organically enriched area. Ophelia 27:197-208

Manly BFJ (1997) Randomization, bootstrap and Monte Carlo methods in biology, 2nd edn. Chapman \& Hall, London

McErlean AJ (1964) Characteristics of Macoma balthica pop- 
ulations in the middle Patuxent Estuary. Chesapeake Sci 5:200-208

McLusky DS, Elliott M (1981) The feeding and survival strategies of estuarine molluscs. In: Jones NV, Wolff WJ (eds) feeding and survival strategies of estuarine organisms. Plenum Press, New York, p 109-121

Menge BA (1991) Relative importance of recruitment and other causes of variation in rocky intertidal community structure. J Exp Mar Biol Ecol 146:69-100

Müller-Haeckel A, Müller K (1982) Population density and distribution of Macoma balthica L. in relation to salinity and food resources in a coastal area of the northern Bothnian Sea. Müller K (ed) Coastal research in the Gulf of Bothnia. Junk W Publishers, The Hague, p 141-149

Myren RT, Pella JJ (1977) Natural variability in distribution of an intertidal population of Macoma balthica subject to potential oil pollution at Port Valdez, Alaska. Mar Biol 41:371-382

Newell R (1965) The role of detritus in the nutrition of two marine deposit-feeders, the prosobranch Hydrobia ulvae and the bivalve Macoma balthica. Proc Zool Soc Lond 144: $25-45$

Nichols FH, Thompson JK (1982) Seasonal growth in the bivalve Macoma balthica near the southern limit of its range. Estuaries 5:110-120

Olafsson EB (1986) Density dependence in suspension feeding and deposit feeding populations of the bivalve Macoma balthica in field experiments. J Anim Ecol 55:517-526

Olafsson EB, Peterson CH, Ambrose WGJ (1994) Does recruitment limitation structure populations and communities of macro invertebrates in marine soft sediments: the relative significance of pre- and post settlement processes. Oceanogr Mar Biol Annu Rev 32:65-109

Peterson CH (1982) The importance of predation and intraand interspecific competition in the population biology of two infaunal suspension-feeding bivalves, Protothaca staminea and Chione undatella. Ecol Monogr 52:437-475

Peterson CH (1991) Intertidal zonation of marine invertebrates in sand and mud. Am Sci 79:236-249

Peterson CH, Andre SV (1980) An experimental analysis of interspecific competition among marine filter feeders in a soft sediment environment. Ecology 61:129-139

Peterson CH, Black R (1987) Resource depletion by active suspension-feeders on tidal flats: influence of local density and tidal elevation. Limnol Oceanogr 32:143-166

Peterson CH, Black R (1988) Responses of growth to elevation fail to explain vertical zonation of suspension feeding bivalves on a tidal flat. Oecologia 76:423-429

Rao CR (1964) The use and interpretation of principal component analysis in applied research. Sankhyaà Ser A 26: 329-358

Ratcliffe PJ, Jones NV, Walters NJ (1981) The survival of Macoma balthica (L.) in mobile sediments. In: Jones NV, Wolff WJ (eds) Feeding and survival strategies of estuarine organisms. Plenum Press, New York, p 91-108

Reading CJ (1979) Changes in the downshore distribution of Macoma balthica (L.) in relation to shell length. Estuar Coast Mar Sci 8:1-13

Rhoads DC, Young DC (1970) The influence of deposit-feeding organisms on sediment stability and community trophic structure. J Mar Res 28:150-177

Ricker WE (1958) Handbook of computations for biological statistics of fish populations. Bull Fish Res Board Can 119

Risk MJ, Moffat JS (1977) Sedimentological significance of fecal pellets of Macoma balthica in the Minas Basin Bay of Fundy. J Sediment Petrol 47:1425-1436
SAS Institute Inc. (1988) SAS/STAT user's guide, Release 6.03 edn. SAS Institute Inc, Cary, NC

Segerstråle SG (1960) Investigations on Baltic populations of the bivalve Macoma balthica (L.). Part I. Introduction. Studies on the recruitment and its relation to depth in Finnish coastal waters during the period 1922-1959. Age and growth. Comment Soc Sci Fenn Biol 23:1-72

Snelgrove PVR, Butman CA (1994) Animal sediment relationships revisited: cause versus effect. Oceanogr Mar Biol Annu Rev 32:111-177

Sokal RR, Rohlf FJ (1995) Biometry. The principles and practice of statistics in biological research, 3rd edn. WH Freeman \& Co, New York

ter Braak CJF, Smilauer P (1998) CANOCO reference manual and user's guide to Canoco for Windows: software for Canonical Community Ordination (version 4). Microcomputer Power, Ithaca, NY

Thompson RJ (1979) Fecundity and reproductive effort in the blue mussel (Mytilus edulis), the sea urchin (Strongylocentrotus droebachiensis), and the snow crab (Chionoecetes opilio) from populations in Nova Scotia and Newfoundland. J Fish Res Board Can 36:955-964

Thompson RJ (1982) The relationship between food ration and reproductive effort in the green sea urchin, Strongylocentrotus droebachiensis. Oecologia 56:50-57

Thompson RJ (1984) Production, reproductive effort, reproductive value and reproductive cost in a population of the blue mussel Mytilus edulis, from a subarctic environment. Mar Ecol Prog Ser 16:249-257

Thorson G (1957) Bottom communities. Mem Geol Soc Am 67: 461-534

Thrush SF, Hewitt JE, Pridmore RD (1989) Patterns in the spatial arrangements of polychaetes and bivalves in intertidal sandflats. Mar Biol 102:529-535

Tunnicliffe V, Risk MJ (1977) Relationships between the bivalve Macoma balthica and bacteria in intertidal sediments: Minas Basin, Bay of Fundy. J Mar Res 35:499-507

Turk TR, Risk MJ, Hirtle RWM, Yeo RK (1980) Sedimentological and biological changes in the Windsor mudflat, an area of induced siltation. Can J Fish Aquat Sci 37: $1387-1397$

Turner SJ, Thrush SF, Pridmore RD, Hewitt JE, Cummings VJ, MaSkery M (1995) Are soft sediment communities stable? An example from a windy harbour. Mar Ecol Prog Ser 120:219-230

Vincent B, Brassard C, Harvey M (1987) Variations de la croissance de la coquille, et de la structure d'âge du bivalve Macoma balthica (L.) dans une population intertidale de l'estuaire du Saint-Laurent (Quebec). Can J Zool 65:1906-1916

Vincent B, Joly D, Brassard C (1989) Effets de la densité sur la croissance du bivalve Macoma balthica (L.) en zone intertidale. J Exp Mar Biol Ecol 126:145-162

Vincent B, Joly D, Harvey M (1994) Spatial variation in growth of the bivalve Macoma balthica (L.) on a tidal flat: effects of environmental factors and intraspecific competition. J Exp Mar Biol Ecol 181:223-238

Wanink JH, Zwarts L (1993) Environmental effects on the growth rate of intertidal invertebrates and some implications for foraging waders. Neth J Sea Res 31:407-418

Wollenberg AL (1977) Redundancy analysis. An alternative for canonical correlation analysis. Psychometrika 42: 207-219

Woodin SA (1974) Polychaete abundance patterns in a marine soft-sediment environment: the importance of biological interactions. Ecol Monogr 44:171-187

Submitted: May 2, 2001; Accepted: August 23, 2001

Proofs received from author(s): April 24, 2002 